\title{
Properties of the Enzymes Catalyzing the Biosynthesis of Lysophosphatidate and Its Ether Analog in Cultured Fibroblasts from Zellweger Syndrome Patients and Normal Controls
}

\author{
KEITH O. WEBBER, NABANITA S. DATTA, AND AMIYA K. HAJRA ${ }^{1}$ \\ Neuroscience Laboratory, Mental Health Research Institute, and Department of Biological Chemistry, \\ University of Michigan, Ann Arbor, Michigan 48109
}

Received September 15, 1986, and in revised form December 15, 1986

The activities, properties, and steady-state kinetics of the five enzymes catalyzing the synthesis of 1-acyl- and 1-alkyl-sn-glycerol 3-phosphate in the cultured skin fibroblasts from Zellweger syndrome patients and normal controls were studied in detail. Judging from their $K_{m}$ and $V_{\max }$ values, glycerol phosphate acyltransferase (EC 2.3.1.15), acyl/ alkyl dihydroxyacetone phosphate reductase (EC 1.1.1.101), and acyl coenzyme A reductase (long-chain alcohol forming), appear to be affected only slightly by the absence of peroxisomes characteristic of the Zellweger syndrome. Glycerophosphate acyltransferase also showed no differences in $N$-ethylmaleimide sensitivity nor in inhibition by dihydroxyacetone phosphate between these cell types. Dihydroxyacetone phosphate acyltransferase (EC 2.3.1.42) and alkyl dihydroxyacetone phosphate synthase (EC 2.5.1.26) have altered activity and kinetic constants in homogenates from Zellweger syndrome fibroblasts. Dihydroxyacetone phosphate acyltransferase has similar $K_{m}$ (DHAP) values in both control and Zellweger syndrome cells; however, the value for the $V_{\max }$ in Zellweger syndrome cells is only $6 \%$ of that found in the controls. This is interpreted as indicating that this enzyme is not defective in this disease but is simply present at a depressed level. Also, this enzyme activity has a maximum rate at $\mathrm{pH} 7.0-$ 7.5 in the mutant cells as opposed to $\mathrm{pH} 5.4$ in the controls. Acylation of dihydroxyacetone phosphate by control cell homogenate was stimulated by $N$-ethylmaleimide at both $\mathrm{pH}$ 5.7 and 7.5 whereas this activity from Zellweger syndrome cells was slightly inhibited at $\mathrm{pH} 5.7$ and strongly inhibited at $\mathrm{pH}$ 7.5. In the absence of detergent, dihydroxyacetone phosphate acyltransferase in the Zellweger syndrome cells was much more labile to trypsin than in the control cells. Alkyl dihydroxyacetone phosphate synthase had a slightly higher $K_{m}(33$ vs $17 \mu \mathrm{M})$ for palmitoyl dihydroxyacetone phosphate and a lower $V_{\max }(0.07$ vs $0.24 \mathrm{mU} / \mathrm{mg}$ protein) in the Zellweger syndrome cells as compared to controls. Although this is a substantial decrease in activity, it probably contributes little to the decreased rate of ether lipid synthesis in these cells. The major problem in this respect is apparently the loss of dihydroxyacetone phosphate acyltransferase activity. All of these enzymes, in both control and Zellweger syndrome cell homogenates, are sedimentable by centrifugation at $100,000 \mathrm{~g}$. Also, with the exception of dihydroxyacetone phosphate acyltransferase they had similar patterns of inactivation by heat in both cell types. 1987 Academic Press, Inc.

Zellweger syndrome $(\mathrm{ZS})^{2}$ is a rare, autosomal-recessive disorder estimated to occur in more than one out of 100,000 live

\footnotetext{
${ }^{1}$ To whom correspondence should be addressed.

${ }^{2}$ Abbreviations used: DHAP, dihydroxyacetone phosphate; GP, sn-glycerol 3-phosphate; AT, acyltransferase; Mes, 4-morpholone-ethane-sulfonic acid; ZS, Zellweger syndrome; NEM, $N$-ethylmaleimide; $\mathrm{mU}, \mathrm{nmol} / \mathrm{min}$.
}

births (1). Children with this disease are born with a characteristic facial morphology and soon develop hypotonia and severe neurological dysfunction (2). The progressive loss of liver and kidney function usually results in death within the first postnatal year. Among the associated biochemical abnormalities that have been reported are deficiencies in mitochondrial electron transport (3), pipecolic acid me- 
tabolism (4), bile acid synthesis (5), oxidation of very-long-chain fatty acids (6), and ether lipid biosynthesis (7-9). Clearly the physiological consequences of this disease are extensive. The present work is directed specifically at the aspect of lipid biosynthesis.

The tissues of patients with this disease are virtually devoid of peroxisomes (3). This fact and the discovery by Hajra et al. $(10,11)$ that DHAP acyltransferase (the first enzyme in the pathway of glycerol ether lipid biosynthesis) is localized in liver peroxisomes led Borst to postulate that ZS patients would have a severe deficiency of plasmalogen (12). This was shown to be the case by Heymans et al. (13). Subsequently Lazarow et al. (9), Datta et al. (14), and Schutgens et al. (8) demonstrated that tissues from these patients were deficient in DHAP acyltransferase activity. Further work from our laboratory (7), with cultured skin fibroblasts, extended the biochemical study of this disease to include two other enzymes of the acyl DHAP pathway (acyl/ alkyl DHAP reductase and alkyl DHAP synthase) as well as GP acyltransferase. The present study provides more detailed information concerning the properties and steady-state kinetic parameters of these acyl DHAP pathway enzymes as well as GP acyltransferase and acyl $\mathrm{CoA}$ reductase in normal and ZS fibroblasts.

\section{MATERIALS}

Palmitoyl coenzyme $\Lambda$, trypsin, trypsin inhibitor, $\mathrm{Na}_{2} \mathrm{EDTA}$, and hexadecanol were obtained from Sigma Chemical Co. (St. Louis, MO). Eagle's minimum essential medium (powdered) and fetal calf serum were purchased from GIBCO.

$\left[{ }^{32} \mathrm{P}\right] \mathrm{DHAP}$ and $\left[{ }^{32} \mathrm{P}\right] \mathrm{GP}$ were prepared by the enzymatic phosphorylation of dihydroxyacetone and glycerol, respectively, with $\left[\gamma^{-32} \mathrm{P}\right] \mathrm{ATP}$, as described previously (15). $\left[1{ }^{14} \mathrm{C}\right] \mathrm{Palmitoyl} \mathrm{CoA}$ was chemically prepared from $\left[1-{ }^{14} \mathrm{C}\right]$ palmitic acid and CoASH as described by Bishop and Hajra (16). Acyl and alkyl DHAP were chemically synthesized as described by Hajra et al. (17).

Other compounds were of reagent grade or better.

\section{METHODS}

Zellweger syndrome fibroblast cell lines GM 0228 and GM 4340 were obtained from the Human Mutant
Cell Repository of the National Institute of General Medical Sciences. Cells were cultured in Eagle's minimum essential media (GIBCO) supplemented with $20 \%$ fetal calf serum (GIBCO). Cultures were split 1: 4 at weekly intervals and the medium was changed once between each split. The cells were harvested by first rinsing them with $0.05 \%$ trypsin in isotonic saline containing $5 \mathrm{mM}$ EDTA and then releasing them from the surface with $0.2 \%$ trypsin in saline/EDTA. An equal volume of $0.2 \%$ trypsin inhibitor (soybean, Sigma) in saline was added immediately to stop the proteolytic action. The cells were pelleted at $200 g$ for $8 \mathrm{~min}$ followed by three washes with isotonic saline/ $5 \mathrm{~mm}$ EDTA. The final pellet was stored at $-70^{\circ} \mathrm{C}$ until assay. Prior to assay the cells were ruptured by sonication $(3 \times 15 \mathrm{~s})$ at $0^{\circ} \mathrm{C}$ in $0.25 \mathrm{M}$ sucrose- $1 \mathrm{mM}$ EDTA with a miniprobe sonicator (Kontes Inst.). The homogenate was centrifuged at $1000 \mathrm{~g}$ for $10 \mathrm{~min}$ to pellet unbroken cells. The supernatant was used for assays.

DHAP acyltransferase and GP acyltransferase were assayed by measuring the amount of labeled lipid formed from the ${ }^{32} \mathrm{P}$-labeled DHAP or GP and palmitoyl coenzyme $\mathbf{A}$ as described previously $(10,15)$ except that substrates with high specific radioactivity $\left(2 \times 10^{4} \mathrm{cpm} / \mathrm{nmol}\right)$ were used for a higher sensitivity. The assay mixture contained $75 \mathrm{mM}$ Tris- $\mathrm{Cl}(\mathrm{pH} 7.5)$ or Mes (pH 5.7), $83 \mu \mathrm{M}$ palmitoyl CoA, $8.3 \mathrm{mM} \mathrm{NaF}$, $8.3 \mathrm{mM} \mathrm{MgCl}_{2}, 0.42 \mathrm{mM}$ DHAP or GP, plus bovine serum albumin $(1.67 \mathrm{mg} / \mathrm{ml}$ for DHAP acyltransferase or $2.5 \mathrm{mg} / \mathrm{ml}$ for GP acyltransferase) in a total volume of $0.6 \mathrm{ml}$ including cell homogenate. After a 15-min incubation at $37^{\circ} \mathrm{C}$ lipids were extracted by an acidic Bligh and Dyer method (18) and dried and radioactive products were determined by liquid scintillation counting. Acyl/alkyl DHAP reductase was assayed by measuring the amount of radioactive lipid formed from B-[4- $\left.{ }^{3} \mathrm{H}\right] \mathrm{NADPH}$ and 1-0-hexadecyl DHAP (19). Alkyl DHAP synthase was assayed by measuring the amount of alkali-stable lipid formed from palmitoyl ${ }^{32}$ P]DHAP and hexadecanol (20) or the amount of radioactive polar product formed from $\left[1-{ }^{14} \mathrm{C}\right]-$ hexadecanol and palmitoyl DHAP (20). Acyl coenzyme A reductase was assayed by measuring the amount of radioactive hexadecanol formed from $\left[1-{ }^{14} \mathrm{C}\right]-$ palmitoyl coenzyme A and NADPH by a modification of the procedure of Bishop and Hajra (21). The assay mixture contained $12.3 \mu \mathrm{M}\left[1-^{14} \mathrm{C}\right]$ palmitoyl $\mathrm{CoA}$ $(123,000 \mathrm{cpm} / \mathrm{nmol}), 1.2 \mathrm{mg} / \mathrm{ml}$ bovine serum albumin, $10 \mathrm{mM} \mathrm{MgCl}, 1 \mathrm{mM}$ glucose 6-phosphate, $57.5 \mathrm{mU}$ glucose-6-phosphate dehydrogenase, and NADPH (usually $60 \mu \mathrm{M}$ ) plus fibroblast homogenate in a total volume of $0.5 \mathrm{ml}$. After incubation at $37^{\circ} \mathrm{C}$ for $40 \mathrm{~min}$, lipids were extracted and washed according to Bligh and Dyer (22). The lipids were separated by TLC with $\mathrm{CHCl}_{3}-\mathrm{CH}_{3} \mathrm{OH}-7.3$ м NH $4 \mathrm{OH}(92 / 2 / 08$, v/v). Radioactive hexadecanol was located by autoradiography $\left(R_{f}=0.45\right)$, scraped out, and counted in a lipid scin- 
tillation counter. Protein content of samples was assayed by the method of Lowry et al. (23) with bovine serum albumin as the standard.

\section{RESULTS}

The relative rates of acylation of DHAP and GP by homogenates of ZS and control cells at various $\mathrm{pH}$ values is shown in Fig. 1. In the control cells, the maximum rates of acylation of DHAP and GP occur at $\mathrm{pH}$ 5.4 and 7.0, respectively. In the ZS cells, the effect of $\mathrm{pH}$ on $\mathrm{GP}$ acylation is normal; however, acylation of DHAP shows a maximum at $\mathrm{pH}$ 7-7.5 with another peak at $\mathrm{pH}$ 5.5. The relative activity of DHAP acyltransferase in $\mathrm{ZS}$ cells is $2 \%$ at $\mathrm{pH} 5.4$ and $12 \%$ at $\mathrm{pH} 7.0$ of the control values (Fig. 1).
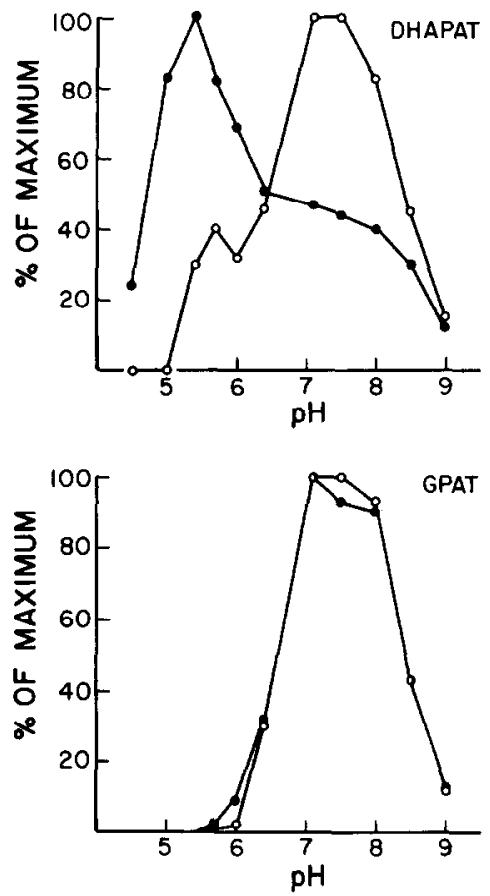

FiG. 1. Effect of assay pH on the rate of acyl DHAP formation by homogenates of control and ZS fibroblasts. Assay conditions are given in text. $\bullet=$ control; $\mathrm{O}=$ ZS. Maximum activities for DHAP acyltransferase are 0.71 and $0.04 \mathrm{mU} / \mathrm{mg}$ protein for control and $\mathrm{ZS}$, respectively. Maximum activities for GP acyltransferase are 0.73 and $1.00 \mathrm{mU} / \mathrm{mg}$ for control and $\mathrm{ZS}$, respectively. Assays contained $70 \mu \mathrm{g}$ cell protein. Buffers used are as follows: $\mathrm{pH} 4.5$ to 5.0 , acetate; $\mathrm{pH}$ 5.4 to 6.4, Mes; $\mathrm{pH} 7.1$ to 9.0 , Tris.
The dependence of the DHAP acyltransferase-catalyzed reaction (the acylation of DHAP by palmitoyl CoA) on the concentration of DHAP was examined in both ZS and control fibroblasts at $\mathrm{pH}$ 5.7. The results are presented graphically in Fig. 2 in the double-reciprocal format. Linear regression analysis revealed a biphasic pattern in the data for both cell types. Two sets of $K_{m}$ and $V_{\max }$ values were apparent, one operating at low to moderate DHAP concentrations (30-250 $\mu \mathrm{M})$ and a second set which is seen at higher substrate concentrations. Similar results have been reported for this enzyme from guinea pig liver $(24,25)$. The Michaelis constant $\left(K_{m}\right)$ for DHAP at low concentrations is virtually identical for both cell types; the value for the ZS fibroblasts is $65 \mu \mathrm{M}$ DHAP and that for the control cells is $68 \mu \mathrm{M}$. The $V_{\max }$ values, on the other hand, were dramatically different. The enzyme in the control cell homogenates showed a maximum velocity of $0.52 \mathrm{mU} / \mathrm{mg}$ protein while the $\mathrm{ZS}$ enzyme gave only $0.03 \mathrm{mU} / \mathrm{mg}$ protein. The $K_{m}$ and $V_{\max }$ values at high DHAP concentrations were $0.33 \mathrm{mM}$ and $0.83 \mathrm{mU} / \mathrm{mg}$ for the control cells and $0.23 \mathrm{~mm}$ and 0.05 $\mathrm{mU} / \mathrm{mg}$ for the ZS cells. The graph of rate of product formation versus cell protein present during assay showed that the activity is linear with up to $100 \mu \mathrm{g}$ of protein in the incubation mixture (Fig. 2, inset).

There appears to be some variation in the levels of enzyme activity from one sample of cells to another. For example, in control cells the activity of DHAP acyltransferase (at $0.42 \mathrm{mM} \mathrm{DHAP}$ ) varied from 0.21 to $0.35 \mathrm{mU} / \mathrm{mg}$ at $\mathrm{pH} 7.4$. This may be due to differences in the age of the cells lines or the cell population density. In a variety of skin fibroblast cultures obtained from different control patients, the DHAP acyltransferase activity was 0.23 $\pm 0.06 \mathrm{mU} / \mathrm{mg}$ (av $\pm \mathrm{SD} ; n=24$ ). Cells from confirmed ZS patients have an average enzyme activity of $0.04 \pm 0.01 \mathrm{mU} / \mathrm{mg}(n$ $=11$ ).

The steady-state kinetics of the GP acyltransferase-catalyzed reaction (acylation of GP by palmitoyl CoA) in these two cell types were also analyzed. These results are presented in Fig. 3. The $K_{m}$ value for GP 


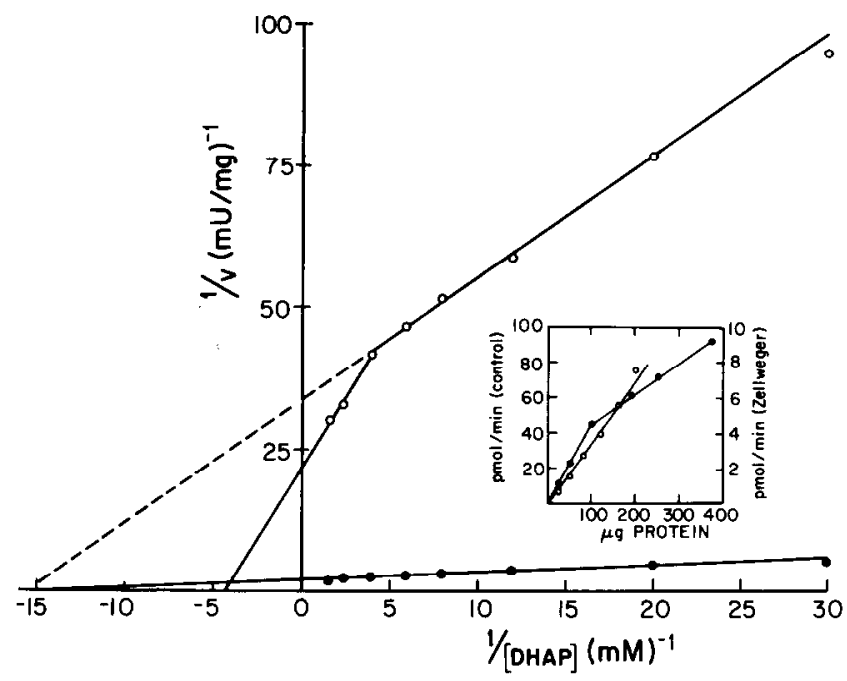

FIG. 2. Effect of increasing DHAP concentration on the rate of acyl DHAP formation by homogenates of control and ZS fibroblasts. Assay conditions are given in text. Palmitoyl CoA concentration is $83 \mu \mathrm{M}$. Assay mixtures contained $95 \mu \mathrm{g}$ cell protein. $\mathrm{pH}=5.7 ; 0=$ control; $\mathrm{O}=\mathrm{ZS}$. Inset shows activity vs [protein] at $0.42 \mathrm{mM}$ DHAP.

was very similar in both the control $(0.55$ $\mathrm{mM})$ and the $\mathrm{ZS}(0.51 \mathrm{mM})$ cells. The enzyme showed a higher maximum velocity in the $\mathrm{ZS}$ cells ( $3.0 \mathrm{mU} / \mathrm{mg}$ protein) as compared to the control cells $(1.8 \mathrm{mU} / \mathrm{mg}$ protein). The enzyme activity was linear with respect to protein up to $100 \mu \mathrm{g}$ (Fig. 3, inset).
The effects of various treatments on the acylation of DHAP and GP in both cell types are compared in Table I. Trypsintreatment produced different effects on DHAP acyltransferase activity in control cells (no inhibition) as compared to ZS cells (76-85\% inhibition) at both $\mathrm{pH} 5.7$ and 7.5 .

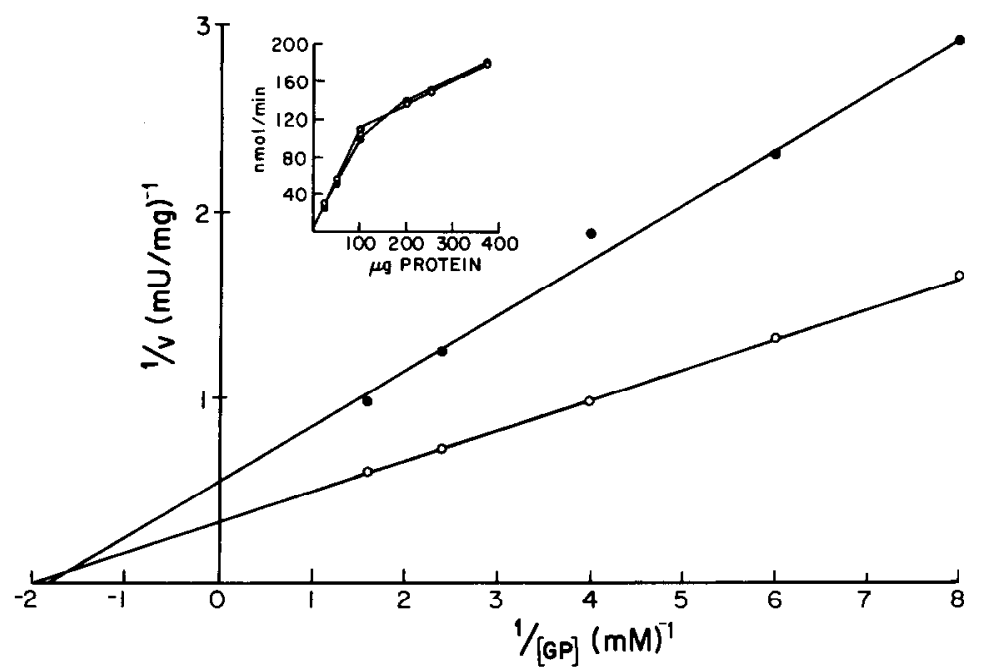

FIG. 3. Effect of increasing GP concentration on the rate of acyl GP formation by homogenates of control and ZS fibroblasts. Assay conditions are given in text. Palmitoyl CoA concentration is 83 $\mu \mathrm{M}$. Assay mixtures contained $88 \mu \mathrm{g}$ cell protein. $\mathrm{pH}=7.5 ;-=$ control; $\mathrm{O}=\mathrm{ZS}$. Inset shows activity vs [protein] at $0.42 \mathrm{mM} \mathrm{GP.}$ 
TABLE I

\begin{tabular}{|c|c|c|}
\hline Treatment & \multicolumn{2}{|c|}{$\%$ of untreated activity } \\
\hline \multicolumn{3}{|l|}{$\operatorname{Trypsin}^{a}$} \\
\hline Control & $\begin{array}{l}100(5.7) \\
105(7.5)\end{array}$ & $10(7.5)$ \\
\hline $\mathrm{ZS}$ & $\begin{array}{l}24(5.7) \\
15(7.5)\end{array}$ & $2(7.5)$ \\
\hline \multicolumn{3}{|l|}{ Heat $^{b}$} \\
\hline Control & $\begin{array}{l}147(5.7) \\
163(7.5)\end{array}$ & $3(7.5)$ \\
\hline $\mathrm{ZS}$ & $\begin{array}{l}58(5.7) \\
14(7.5)\end{array}$ & $1(7.5)$ \\
\hline \multicolumn{3}{|l|}{$\mathrm{NEM}^{c}$} \\
\hline Control & $\begin{array}{l}133(5.7) \\
119(7.5)\end{array}$ & $30(7.5)$ \\
\hline $\mathrm{ZS}$ & $\begin{array}{l}93(5.7) \\
22(7.5)\end{array}$ & $30(7.5)$ \\
\hline \multicolumn{3}{|l|}{$\mathrm{GP}^{d}$} \\
\hline Control & $\begin{array}{l}98(5.7) \\
87(7.5)\end{array}$ & - \\
\hline $\mathrm{ZS}$ & $\begin{array}{l}93(5.7) \\
40(7.5)\end{array}$ & - \\
\hline \multicolumn{3}{|l|}{$\mathrm{DHAP}^{d}$} \\
\hline $\begin{array}{l}\text { Control } \\
\text { ZS }\end{array}$ & - & $\begin{array}{l}53(7.5) \\
53(7.5)\end{array}$ \\
\hline
\end{tabular}

Note. Samples of cell homogenate were either ${ }^{a}$ treated with trypsin $(0.1 \mathrm{mg} / \mathrm{mg}$ cell protein $)$ at $37^{\circ} \mathrm{C}$ for $10 \mathrm{~min}$ prior to assay; ${ }^{b}$ heated at $45^{\circ} \mathrm{C}$ for $10 \mathrm{~min}$ prior to assay; "treated with $100 \mu \mathrm{M}$ NEM for $10 \mathrm{~min}$ prior to assay; or ${ }^{d}$ assayed in the presence of $5 \mu \mathrm{M}$ unlabeled GP or DHAP. Untreated activities were as follows: 0.56 and $0.40 \mathrm{mU} / \mathrm{mg}$ for DHAP acyltransferase in control cells at $\mathrm{pH} 5.7$ and 7.5 respectively; 0.02 and $0.09 \mathrm{mU} / \mathrm{mg}$ for DHAP acyltransferase in $\mathrm{ZS}$ cells at $\mathrm{pH} 5.7$ and 7.5 respectively. 0.8 and 1.4 $\mathrm{mU} / \mathrm{mg}$ for GP acyltransferase in control and $\mathrm{ZS}$ cells, respectively.

GP acyltransferase activity, on the other hand, was labile towards trypsin in both the cell types. Heating samples of cell homogenate to $45^{\circ} \mathrm{C}$ for $10 \mathrm{~min}$ destroyed virtually all of the GP acyltransferase activity in both cell types and a large portion of the DHAP acyltransferase activity in the ZS cells; however, the DHAP acyltransferase in the control cell homogenate was actually increased by $50-60 \%$. The DHAP acyltransferase activity of $\mathrm{ZS}$ cells acting at pH 7.5 appears to be more labile to heat than is the pH 5.7 activity (Table I).
NEM has a stimulating effect on the acylation of DHAP by homogenates from control cells at both $\mathrm{pH} 5.7$ and 7.5. In ZS cell homogenates, NEM has an inhibitory effect on this reaction; however, its effect is much more pronounced at $\mathrm{pH} 7.5$ than at pII 5.7. This is similar to the effect of heat noted above. GP acyltransferase is inhibited by NEM to the same extent $(70 \%)$ in both $\mathrm{ZS}$ and control cell homogenates (Table I).

When $5 \mathrm{~mm}$ GP is added to the DHAP acyltransferase assay mixture it has only a small effect on the reaction at $\mathrm{pH} 5.7$ in homogenates of both cell types. At $\mathrm{pH} 7.5$, a slight inhibition (13\%) by GP was observed for the control cells but quite a substantial inhibition was found $(60 \%)$ in the ZS cell homogenate. DHAP, on the other hand, strongly inhibits the acylation of GP to the same extent ( $47 \%$ ) in both cell types.

The reduction of alkyl DHAP by NADPH, catalyzed by acyl/alkyl DHAP reductase, was analyzed with respect to its dependence on the NADPH concentration. The double-reciprocal plots for this enzyme are given in Fig. 4. The $V_{\max }$ was essentially the same for both cell types with values of 0.62 and $0.64 \mathrm{mU} / \mathrm{mg}$ protein being found in the control and ZS lines, respectively. The $K_{m}$ for NADPH was also similar for both cell lines. The ZS cell line showed a value of $5.4 \mu \mathrm{M}$ while the $K_{m}$ of the control line was $5.1 \mu \mathrm{M}$. Enzyme activity was linear with respect to protein up to $175 \mu \mathrm{g}$ (Fig. 4, inset).

Alkyl DHAP synthase, which forms the ether linkage in eukaryotic glycerol-ether lipids, was characterized with respect to the enzymatic reaction's dependence on the concentration of palmitoyl DHAP. Figure 5 shows the double-reciprocal plots of the resultant data. The enzyme activity in $\mathrm{ZS}$ and control fibroblasts differed in both $K_{m}$ and $V_{\max }$. The values for the control cells were $17 \mu \mathrm{M}$ and $0.24 \mathrm{mU} / \mathrm{mg}$ protein, while those for the ZS cells were $30 \mu \mathrm{M}$ and 0.07 $\mathrm{mU} / \mathrm{mg}$ protein. Enzyme activity was linear with respect to protein up to at least $90 \mu \mathrm{g}$ (Fig. 5, inset).

When acyl coenzyme A reductase was assayed while varying the concentration of NADPH (Fig. 6), only a small difference 


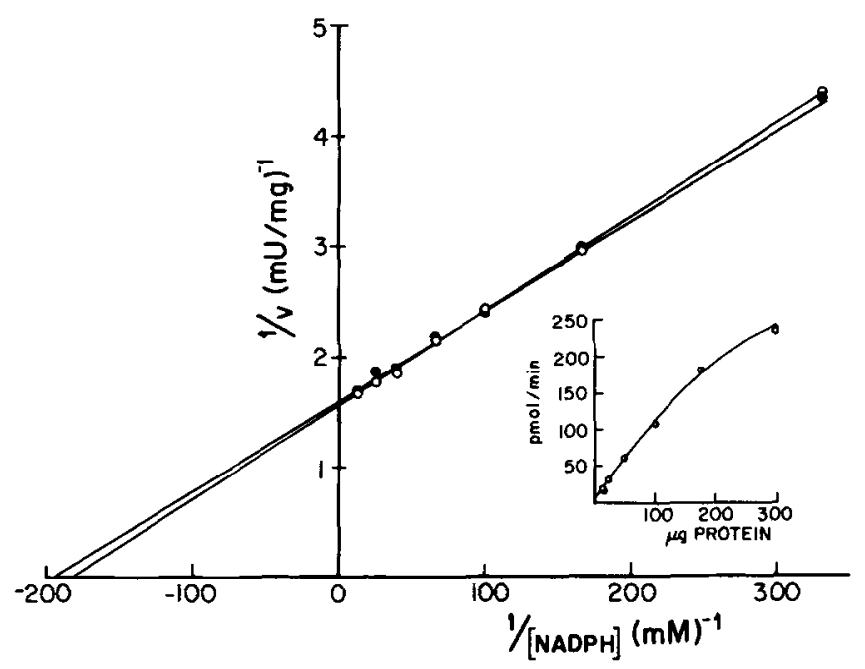

FIG. 4. Effect of increasing NADPH concentration on the rate of acyl DHAP reduction with enzyme from control and ZS fibroblasts. Assay conditions are given in text. Palmitoyl DHAP concentration is $0.2 \mathrm{mM}$. Assay mixtures contained $45 \mu \mathrm{g}$ cell protein. $=$ control; $\mathrm{O}=\mathrm{ZS}$. Inset shows activity vs [protein] at $70 \mu \mathrm{M} \mathrm{NADPH}$.

was found in the values for $V_{\max }(1.18$ and $1.08 \mathrm{nmol} / \mathrm{h} / \mathrm{mg}$ protein for the control and ZS cells, respectively). The control cells showed a slightly higher $K_{m}$ for NADPH $(12.8 \mu \mathrm{M})$ as compared to the ZS cells $(9.9$ $\mu \mathrm{M})$. Enzyme activity was linear with respect to protein up to approximately 100 $\mu \mathrm{g}$ (Fig. 6, inset).
Figure 7 compares the sensitivity to the thermal inactivation of acyl/alkyl DHAP reductase, alkyl DHAP synthase, and acyl CoA reductase in both cell types, Both reductases were substantially inactivated by heating to $50^{\circ} \mathrm{C}$ for $20-30$ min whereas alkyl DHAP synthase was only moderately affected by this treatment. Surprisingly,

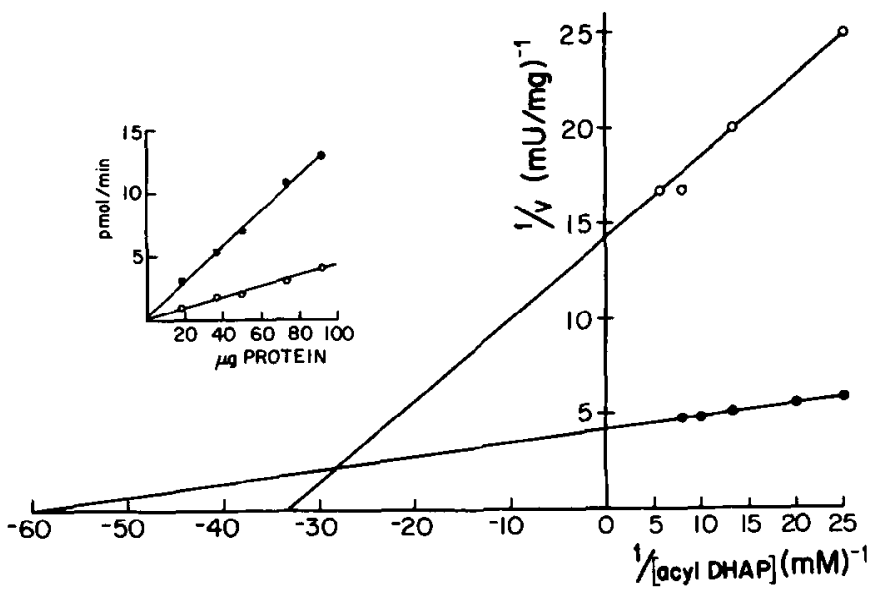

FIG. 5. Effect of increasing palmitoyl DHAP concentration on the formation of hexadecyl DHAP by homogenates of control and ZS fibroblasts. Assay conditions are given in the text. Hexadecanol concentration is $50 \mu \mathrm{M}$. Assay mixtures contained $73 \mu \mathrm{g}$ cell protein. $0=$ control; $\mathrm{O}=\mathrm{ZS}$. Inset shows activity vs [protein] at $75 \mu \mathrm{M}$ palmitoyl DHAP. 


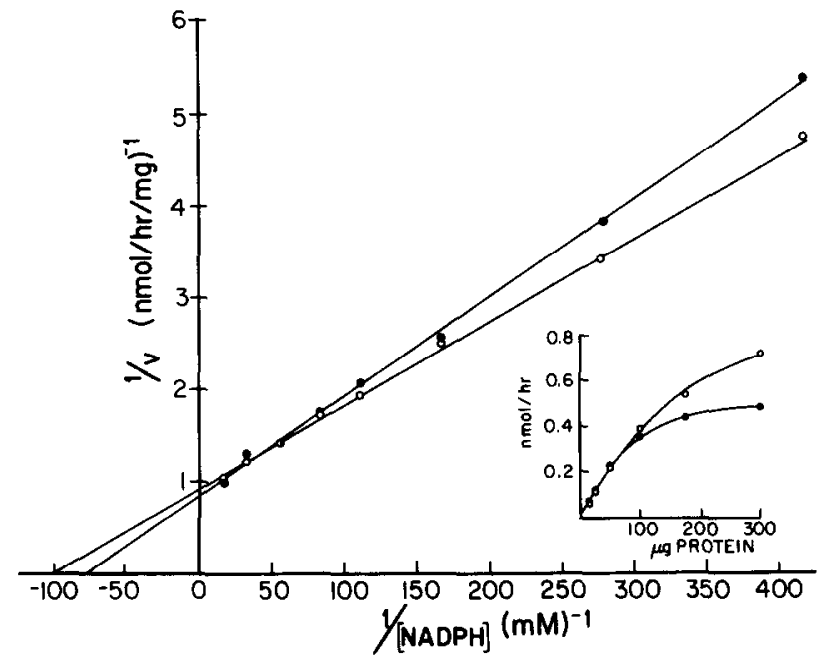

FIG. 6. Effect of increasing NADPH concentration on the reduction of palmitoyl CoA to hexadecanol with the enzyme from control and ZS fibroblasts. Assay conditions are given in text. Palmitoyl CoA concentration is $12.3 \mu \mathrm{M}$. Assay mixtures contained $42 \mu \mathrm{g}$ cell protein. $=$ control; $\mathrm{O}=\mathrm{ZS}$. Inset shows activity vs [protein] at $1.0 \mathrm{mM}$ NADPH.

acyl/alkyl DHAP reductase appears to be more stable in the ZS cells than in the controls. Alkyl DHAP synthase and acyl CoA reductase show a greater loss of activity in the $\mathrm{ZS}$ cell homogenates as compared to controls.

Samples of homogenates of ZS and control cells were centrifuged at $170,000 \mathrm{~g}$ for $60 \mathrm{~min}$ after which the supernatants and pellets were assayed for enzyme activities. As expected from the work of others (26, 27 ), catalase showed a much higher percentage of activity in the supernatant from the ZS cells as compared to that from the control cells ( $90 \mathrm{vs} 40 \%$ ). None of the other enzymes showed substantial differences in sedimentability between these two cell types. The activity in the pellets comprised $75-85 \%$ of the total activity for all except alkyl DHAP synthase which showed $55 \%$ in the pellet.

\section{DISCUSSION}

Although it has previously been established that children born with Zellweger syndrome have markedly lower levels of plasmalogen in their tissues (13), the cause of this deficiency, with respect to enzyme activities and kinetic parameters, has not been clearly established. Earlier work has shown that DHAP acyltransferase activity is nearly absent in tissues and cultured skin fibroblasts from these patients (7-9) and that alkyl DHAP synthase is significantly reduced $(7,28)$; however, it was not determined whether the defects were manifest in the actual numbers of enzyme molecules or in the catalytically active structure of the enzymes themselves.

It was found in this work that the DHAP acyltransferase activity in normal and ZS fibroblasts showed similar $K_{m}$ (DHAP) values while $V_{\max }$ for this enzyme in the ZS cells was decreased by 17 -fold. These results are interpreted most simply as indicating that the deficiency of DHAP acyltransferase activity in these cells is due to a lower concentration of active enzyme molecules rather than a defect in the structure of the protein molecule itself. The cause of such a depletion of active enzyme is unkown. It may be that in the absence of peroxisomes the enzyme is less stable and more quickly degraded as has been demonstrated for acyl CoA oxidase (29) or perhaps less enzyme is synthesized when its natural destination (the peroxisome) is not available. Such a distinction cannot be made from these results. Arias et al. (30) 

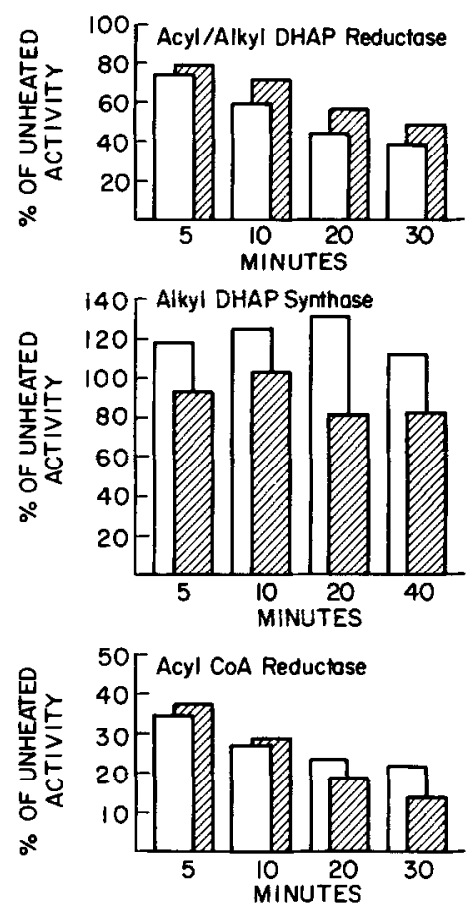

FIG. 7. Samples of cell homogenate were heated at $50^{\circ} \mathrm{C}$ for the specified lengths of time prior to assay. Assay mixtures contained 20-50 $\mu \mathrm{g}$ cell protein. $\square$ $=$ control; 㳑 $=$ ZS.

reported that the ZS cells used in this study have $7-9 \%$ of the normal number of peroxisomes found in control fibroblasts. Therefore, the level of DHAP acyltransferase roughly reflects the level of peroxisomes in these cells. This is not the case with catalase which is present at normal levels (26). It was considered that DHAP acyltransferase in $\mathrm{ZS}$ cells may not be membrane bound and therefore less catalytically active. However, when homogenates of ZS fibroblasts were centrifuged at $170,000 \mathrm{~g}$ for $60 \mathrm{~min}$ virtually all of the DHAP acyltransferase activity was found in the pellet, indicating that the enzyme is membrane bound in these cells. It was also found that in ZS cell homogenates DHAP acyltransferase is labile to trypsin in the absence of detergent, whereas in homogenates of control cells disruption of the membranes by detergent is required before the enzyme can be inactivated by proteolysis (Table I). This is strong evidence that either the enzyme faces the lumenal side of the membrane in normal cells but the cytoplasmic side in $\mathrm{ZS}$ cells or that this membrane-bound enzyme is not vesicular in ZS cells. Such a difference in orientation may be relevant to the mechanism of incorporation of the enzyme into the peroxisomal membrane $(31,32)$. An alternate explanation is an increased fragility of the few peroxisomes present in the diseased cells leading to substantial breakage during cell homogenization.

In contrast to a previous report from this laboratory (7), the activity of GP acyltransferase in ZS fibroblasts was found to be normal to slightly elevated. This is not an unexpected finding since GP acyltransferase is known to be localized to the endoplasmic reticulum and mitochondria in other cell types and therefore no alteration in activity by a depletion of peroxisomes should be expected. Although mitochondrial abnormalities are associated with this disease, they apparently do not affect the activity of GP acyltransferase or, if they do, then the effect is compensated by the microsomal enzyme pool. This point needs to be investigated further. The previous finding of lower activity (7) is probably due to the fact that trypsin inhibitor was not being added before the harvested cells were washed. GP acyltransferase is especially labile towards trypsin treatment; however, addition of trypsin inhibitor was found to have a protective effect on nearly all the enzymes we routinely assayed.

The increase in $V_{\max }$ for GP acyltransferase found in the ZS cells may be physiologically necessary to balance the loss of DHAP acyltransferase activity since both of these enzymes are involved in the synthesis of lysophosphatidate. It is also known that fibroblasts from ZS patients substitute diacyl glycerolipids on a nearly equivalent basis for the missing alkyl/acyl and alkenyl/acyl glycerolipids $(33,34)$.

The NEM-induced increase in DHAP acyltransferase activity in the control cell homogenates is probably due to inhibition of competing enzymes (e.g., acyl CoA hydrolase, GP acyltransferase, etc.) or possibly could be due to removal of the prod- 
uct, coenzyme A. This stimulation of DHAP acyltransferase by NEM has also been observed in liver (24).

The properties of DHAP acyltransferase in ZS are quite different than the corresponding enzyme in the normal cells. For example, ZS DHAP acyltranferase is more labile towards trypsin and heat and more inhibited by NEM than the control. In this respect the ZS DHAP acyltransferase is similar to GP acyltransferase which raises an interesting question, i.e., whether or not the residual activity of DHAP acyltransferase in ZS is due to the nonspecificity of GP acyltransferase. Microsomal GP acyltransferase has been postulated to have dual catalytic activity (35). Though it is not evident with the normal cells, it is possible that GP acyltransferase catalyzes the acylation of DHAP at $4 \%$ the rate of GP acylation so that it becomes apparent only when $95 \%$ of the masking DHAP acyltransferase is absent. On the other hand, at $\mathrm{pH} 5.7$ (where GP acyltransferase is inactive) DHAP acyltransferase in ZS cells (but not in normal controls) is labile towards trypsin and heat, indicating that in $\mathrm{ZS}$ cells residual DHAP acyltransferase is present but its properties are different than in normal cells. Nevertheless, assuming that the DHAP acyltransferase in ZS has the same $\mathrm{pH}$ activity profile as the normal control it could be calculated that $80 \%$ of the $\mathrm{pH} 7.5 \mathrm{DHAP}$ acyltransferase activity is due to GP acyltransferase. Further evidence for this interpretation is that unlabeled GP added to the DHAP acyltransferase assay at 12 times the DHAP concentration inhibited DHAP acyltransferase activity by $60 \%$ at $\mathrm{pH} 7.5$ (Table I) in the ZS cells. From these results it can be concluded that the rate of acylation of DHAP by GP acyltransferase is negligible (2-4\%) compared to the DHAP acyltransferase activity in normal controls. Residual DHAP acyltransferase activity in ZS cells is only $2-3 \%$ of normal cells.

Acyl/alkyl DHAP reductase shows no significant difference in activity between control and ZS fibroblasts. Therefore, the activity of this enzyme is presumably not a contributing factor to the low levels of ether lipids characteristic of this disease.
On the other hand, alkyl DHAP synthase has abnormal kinetic constants in the ZS cells. The $V_{\max }$ for alkyl DHAP synthase in these cells is only $30 \%$ of the normal value and the $K_{m}$ value for acyl DHAP is approximately doubled (17 vs $30 \mu \mathrm{M}$ ). A 70\% decrease in activity was reported previously (7); however; those results did not reflect the maximum velocity of the enzyme. Schrakamp et al. (28) have reported a $K_{m}$ value for palmitoyl DHAP of $30 \mu \mathrm{M}$ and a $V_{\max }$ of $0.13 \mathrm{mU} / \mathrm{mg}$ in cultured normal skin fibroblasts. Their finding of lower activity than reported here may be due to residual trypsin from the harvesting procedure as mentioned above. We have found reduced enzyme activities when the trypsinization was not stopped with trypsin inhibitor.

Although it is not possible to say with certainty what is occurring in the living cell, these results would indicate that alkyl DIIAP synthase activity is not rate limiting in the formation of alkyl DHAP in ZS fibroblasts since the absolute activity of DHAP acyltransferase is lower than that of alkyl DHAP synthase. However, the actual catalytic rates of these enzymes in the cell will depend not only on their substrate concentrations in the vicinity of each enzyme but very possibly on other factors as well (e.g., allosteric effects, subcellular location, etc.).

Acyl coenzyme A reductase, which produces the long-chain alcohols required for glycerol ether lipid synthesis, was found to have a normal $V_{\max }$ in the ZS fibroblasts. Although this is not an unexpected result, since little is known of the subcellular distribution of this enzyme, it is an indication that either this enzyme is not normally resident in human fibroblast peroxisomes or else its level is not changed by the inability to become incorporated into these organelles. It is worth mentioning, however, that Bishop and Hajra (21) found preliminary evidence that acyl CoA reductase may be present in rat brain microperoxisomes.

In summary, we have found that, of the four acyl DHAP pathway enzymes and GP acyltransferase, only DHAP acyltransferase and alkyl DHAP synthase are deficient 
in skin fibroblasts from ZS patients. The defect in the biosynthesis of glycerol ether lipids, characteristic of Zellweger syndrome, appears to be attributable to the near absence of DHAP acyltransferase activity although the lower level of alkyl DHAP synthase may also be a contributing factor.

\section{ACKNOWLEDGMENTS}

This work was supported by Grants NS 15747 and NS 08841 from the National Institutes of Health.

\section{REFERENCES}

1. Moser, H. W. (1986) J. Pediatr. 108, 89-91.

2. Bowen, P., LeE, C. S. N., ZELLWEgER, H., AND LINDENBURG, R. (1964) Bull. Johns Hopkins Hosp. $114,402-414$.

3. Goldfischer, S., Moore, C. L., Johnson, A. B., SPIRo, A. J., Valsamis, M. P., WISNIEWSKi, H. K., Ritch, R. H., NorTon, W. T., RAPIN, I., AND GARTNER, L. M. (1973) Science 182, 62-64.

4. Danks, D. M., TrbeetT, P., Adams, C., and CAMPBELL, P. (1975) J. Pediatr. 86, 382-387.

5. EySSen, H., Eggermont, E., VAN ELDERE, J., JAEKFN, J. Pa Rmentier, G., AND JANSSEN, G. (1985) Acta Paediatr. Scand. 74, 539-544.

6. Brown, F. R. III, McAdams, A. J., Cummins, J. W., KoNKOL, R., SnNGH, I., Mosfr, A. R., AND Moser, H. W. (1982) Johns Hopkins Med. J. 151, 344361.

7. DATTA, N. S., WILSON, G. N., and Haira, A. K. (1984) N. Engl. J. Med. 311, 1080-1083.

8. Schutgens, R. B. H., Romeyn, G. J., Wanders, R. J. A., Van DEN Bosch, H., Schrakamp, G., and Heymans, H. S. A. (1984) Biochem. Biophys. Res. Commun 120, 179-184.

9. Lazarow, P., Black, V., Hajra, A. K., DatTa, N. S., Bangaru, B., ANd Dancis, J. (1984) Pediatr. Res. 18, 223a.

10. HAJRA, A. K., BuRKE, C. L., AND JONES, C. L. (1979) $J$. Biol. Chem. 254, 10896-10900.

11. HAJRA, A. K., AND BISHOP, J. E. (1982) Ann. N.Y. Acad. Sci. 386, 170-182.

12. Borst, P. (1983) Trends Biochem. Sci. 8, 269-272.

13. Heymans, H. S. A., Schutgens, R. B. H., TAN, R., VAN DEN BOSCH, H., AND BORST, P. (1983) Nature (London) 306, 69-70.

14. Datta, N. S., Wilson, G. N., and HajRa, A. K. (1984) Fied. Proc. 43, 1653.
15. HajRa, A. K., and Burke, C. L. (1978) J. Neurochem. 31, 125-134.

16. Bishop, J., AND HAJRA, A. K. (1980) Anal Biochem. 106, 344-350.

17. HaJra, A. K., Saraswathi, T. V., and DAS, A. K. (1983) Chem. Phys. Lipids 33, 179-193.

18. HaJRA, A. K. (1974) Lipids 9, 502-505.

19. LABELle, E. F., AND HAJRA, A. K. (1974) J. Biol. Chem. 249, 6936-6944.

20. Davis, P. A., AND HaJRA, A. K. (1981) Arch. Biochem. Biophys. 211, 20-29.

21. Bishop, J. E., AND HAJRA, A. K. (1978) J. Neurochem. 30, 643-647.

22. Bligh, E. G., AND DYeR, W. J. (1959) Canad. $J$. Biochem. 37, 911-917.

23. Lowry, O. H., Rosebrough, N. J., AND FARR, A. L. (1951) J. Biol Chem. 193, 265-275.

24. JONES, C. L., AND HAJRA, A. K. (1980) J. Biol. Chem. 255, 8289-8295.

25. JONES, C. L., AND HAJRA, A. K. (1983) Arch Biochem. Biophys. 226, 155-165.

26. Wanders, R. J. A., Kos, M., Roest, B., MEIJER, A. J., Schrakamp, G., Heymans, H: S. A., TegeLAERS, W. H. H., VAN DEN BOSCH, H., SchUTGENS, R. B. H., AND TAGER, J. M. (1984) Biochem. Biophys. Res. Commun. 123, 1054-1061.

27. Lazarow, P., Black, V., Shio, H., FujIKi, Y., HajRA, A. K., DatTa, N. S., BangaRU, B. S., AND DANCIS, J. (1985) Pediatr. Res. 19, 13561364.

28. Schrakamp, G., Roosenboom, C. F. P.. Schutgens, R. B. H., WANDERS, R. J. A., HEYMaNS, H. S. A., TAGER, J. M., AND VAN DEN BOSCH, H. (1985) J. Lipid Res. 26, 867-873.

29. TAger, J. M., VAN Der. BeEk, W. A. T. H., WaNDers, R. J. A., Hashimoto, T., Heymans, H. S. A., VAN DEN BOSCH, H., SCHUTGENS, R. B. H., AND SChram, A. W. (1985) Biochem. Biophys. Res. Commun. 126, 1269-1275.

30. Arias, J., Moser, A. B., and Golnfischer, S. (1985) J. Cell Biol. 100, 1789-1792.

31. Goldman, B. M., AND Blobet, G. (1978) Proc Natl. Acad. Sci. USA 75, 5066-5070.

32. FujuKI, Y, RACHubINSKI, R. A., AND LAZAROW, P. B. (1984) Proc. Natl. Acad. Sci. USA 81, 71277131.

33. Schrakamp, G., Schutgens, R., Wanders, R., HeYmans, H., TAGER, J., AND VAN DEN BOSCH, H. (1985) Biochim. Biophys. Acta 833, 170-174.

34. Heymans, H. S. A., van den Bosch, H., SchutGENS, R. B. H., TEGELAERS, W. H. H., WALTHER, J. U., MULLER-HeGKeR, J., AND BoRST, P. (1984) Eur. J. Pediatr. 142, 10-15.

35. Bell, R. M., AND Coleman, R. A. (1980) Annu. Rev. Biochem 49, 459-487. 